Fernando Antonio Mourão Valejo

Daniel Guimarães TiezZI

Larissa Raquel Mouro Mandarano

Christiani BISINOTO DE SOUSA

JURANDYR MOREIRA DE ANDRADE

Original Article

Keywords

Breast

Breast neoplasms/surgery

Neoadjuvant therapy

Mastectomy, segmental

Palpation

Palavras-chave

Mama

Neoplasias da mama/cirurgia

Terapia neoadjuvante

Mastectomia segmentar

Palpação

\section{Volume of breast tissue excised during breast-conserving surgery in patients undergoing preoperative systemic therapy}

\author{
Volume de ressecção cirúrgica no tratamento conservador do \\ câncer de mama em pacientes submetidas a tratamento neoadjuvante
}

Abstract

PURPOSE: We aimed to determine whether clinical examination could adequately ascertain the volume of tissue to be resected during breast-conserving surgery after neoadjuvant therapy. METHODS: We reviewed the clinical reports of 279 patients with histologically diagnosed invasive breast carcinomas treated with neoadjuvant therapy followed by surgery or with primary surgery alone. We estimated volumes of excised tissues, the volume of the tumor mass and the optimal volume required for excision based on $1 \mathrm{~cm}$ of clear margins. The actual excess of resected volume was estimated by calculating the resection ratio measured as the volume of the resected specimen divided by the optimal specimen volume. The study endpoints were to analyze the extent of tissue resection and to ascertain the effect of excess resected tissue on surgical margins in both groups of patients. RESULTS: The median tumor diameter was 2.0 and $1.5 \mathrm{~cm}$ in the surgery and neoadjuvant therapy groups, respectively. The median volume of resected mammary tissue was $64.3 \mathrm{~cm}^{3}$ in the primary surgery group and $90.7 \mathrm{~cm}^{3}$ in the neoadjuvant therapy group. The median resection ratios in the primary surgery and neoadjuvant therapy groups were 2.0 and 3.3, respectively ( $<<0.0001)$. Surgical margin data were similar in both groups. Comparison of the volume of resected mammary tissues with the tumor diameters showed a positive correlation in the primary surgery group and no correlation in the neoadjuvant therapy group. CONCLUSION: Surgeons tend to excise large volumes of tissue during breast-conserving surgery after neoadjuvant therapy, thereby resulting in a loss of the correlation between tumor diameter and volume of the excised specimen.

\section{Resumo}

OBJETIVO: Foi determinar se a avaliação clínica é adequada na determinação do volume a ser ressecado em cirurgias conservadoras de mama após tratamento neoadjuvante. MÉTODOS: Avaliamos 279 pacientes com diagnóstico histológico de carcinoma invasor de mama submetidas à terapia neoadjuvante seguida de tratamento cirúrgico ou tratadas com cirurgia primária. $\bigcirc$ volume de tecido excisado, o volume da massa tumoral e o volume ótimo para a excissão cirúrgica baseado em uma margem de $1 \mathrm{~cm}$ foram calculados. $\bigcirc$ excesso de volume excisado foi estimado pelo cálculo da taxa de ressecção determinada pelo volume de tecido excisado dividido pelo volume ótimo para a excisão cirúrgica. Analisamos a extensão da ressecção cirúrgica e o efeito do exesso de tecido ressecado na obtenção de margens cirúrgicas. RESULTADOS: A mediana do diâmetro tumoral foi de 2,0 e 1,5 cm nos grupos de cirurgia primária e terapia neoadjuvante, respectivamente. A mediana do volume de tecido mamário ressecado foi de $64,3 \mathrm{~cm}^{3}$ no grupo de cirurgia primária e de $90,7 \mathrm{~cm}^{3}$ no grupo de tratamento neoadjuvante. A taxa mediana de ressecção nos grupos de cirurgia primária e terapia neoadjuvante foram 2,0 e 3,3 respectivamente ( $p<0,0001)$. Os dados relacionados à margem cirúrgica foram similares em ambos os grupos. A comparação do volume de tecido ressecado mostrou correlação positiva no grupo de cirurgia primária, porém não no grupo de tratamento neoadjuvante. CONCLUSÃO: Existe uma tendência dos cirurgiões a removerem maior quantidade de tecido mamário durante cirurgias conservadoras de mama de pacientes que foram submetidas à tratamento neoadjuvante, resultando na perda da correlação entre o diâmetro tumoral e o volume do espécime excisado.
Correspondence

Daniel Guimarães Tiezzl

3900 Bandeirantes Avenue

Zip code: $14048-900$

Ribeirāo Preto (SP), Brazi

Received

$03 / 20 / 2013$
Study carried out at Breast Disease Division, Obstetrics and Gynecology Department, Faculdade de Medicina de Ribeirão Preto, Universidade de São Paulo - USP - Ribeirão Preto (SP), Brazil.

Breast Disease Division, Obstetrics and Gynecology Department, Faculdade de Medicina de Ribeirão Preto - USP - Universidade de São Paulo (USP) - Ribeirão Preto (SP), Brazil.

Conflict of interest: none. 


\section{Introduction}

Breast-conserving surgery (BCS) is the standard treatment for early-stage breast cancer patients. Long-term follow-up studies have reported comparable disease-free and overall survival rates between patients undergoing mastectomy and $\mathrm{BCS}^{1,2}$. Use of neoadjuvant therapy is an option for increasing the rate of breast-conserving surgery in breast cancer patients ${ }^{3}$. Patients initially scheduled to undergo mastectomy achieve comparable control of focal lesions and favorable disease-free and overall survival rates after undergoing neoadjuvant therapy followed by $\mathrm{BCS}^{4-7}$.

$\mathrm{BCS}$ results in a better cosmetic outcome than mastectomy, alleviating post-surgical psychological stress. Although BCS is the least invasive surgical technique for breast cancer treatment, cosmetic outcomes vary widely. Cosmetic failure rates of up to $40 \%$ have been reported. Many factors affect cosmetic outcomes after BCS. However, the volume of excised breast tissue is the most important factor that affects patient satisfaction regarding cosmetic outcomes after $\mathrm{BCS}^{8-11}$.

The volume of breast tissue to be excised during BCS is usually estimated by palpation and depends on tumor size. There is a positive association between excised volumes and presence of clear margins in patients undergoing primary BCS, and the positive resection margins in up to $41 \%$ of patients in palpation-guided surgery ${ }^{12-14}$. Neoadjuvant therapy causes non-concentric tumor shrinkage in up to $52 \%$ of patients. Among patients showing complete clinical responses, about $35 \%$ achieves complete pathological response ${ }^{15}$. There is no report how neoadjuvant treatment interferes with the accuracy of breast tissue resection in conservative procedures. The objective of this study was to evaluate the effects of neoadjuvant therapy on the resected volumes during breast-conserving surgeries.

\section{Methods}

We retrospectively reviewed the clinical reports of 279 patients with histological diagnoses of invasive breast carcinomas. Patients were treated with BCS at the Hospital das Clínicas of the Ribeirão Preto School of Medicine, University of São Paulo, between January 1990 and December 2003. No oncoplastic procedure was performed as breast conserving therapy. Our institutional review board approved the study design. A total of $191 \mathrm{pa}-$ tients who underwent primary surgery and were at stage I, IIa and IIb (T2N1M0) with $\mathrm{T} \leq 3 \mathrm{~cm}$ constituted the early breast cancer (EBC) group. The remaining 88 patients who received neoadjuvant treatment followed by BCS and were at stage IIa (T2NOM0) with T $\geq 3 \mathrm{~cm}$, IIb (excluding $\mathrm{T} 2 \mathrm{~N} 1 \mathrm{M} 0$ with $\mathrm{T} \leq 3 \mathrm{~cm}$ ) and III constituted the locally advanced breast cancer (LABC) group. Most patients $(\mathrm{n}=73)$ were treated with exclusive neoadjuvant chemotherapy. Thirty-nine patients received a combination of docetaxel $\left(75 \mathrm{mg} / \mathrm{m}^{2}\right)+$ epirrubicin $\left(60 \mathrm{mg} / \mathrm{m}^{2}\right)$. FEC60 (fluoruracil $600 \mathrm{mg} / \mathrm{m}^{2}$, epirubicin $60 \mathrm{mg} / \mathrm{m}^{2}$, cyclophosphamide $600 \mathrm{mg} / \mathrm{m} 2) 25$ patients; paclitaxel $\left(135 \mathrm{mg} / \mathrm{m}^{2}\right)$ and epirubicin $\left(60 \mathrm{mg} / \mathrm{m}^{2}\right)$ patients; epirubicin $\left(60 \mathrm{mg} / \mathrm{m}^{2}\right)$ and cyclophosphamide $\left(600 \mathrm{mg} / \mathrm{m}^{2}\right)$ one patient; sequential FEC60 and docetaxel/epirubicin patients or a combination of taxane plus trastuzumab patients. All squemes were i.v. infusion D1 each 21/21 days.

Thirteen patients were subjected to neoadjuvant hormone therapy: tamoxifen $20 \mathrm{mg}$ (11 patients) or letrozol $2.5 \mathrm{mg}$ (two patients) both P.O. daily. The remaining two patients were treated with chemo and hormone therapy combination (FEC60 or docetaxel/epirubicin plus tamoxifen). Neoadjuvant therapy was administered until allowing BCS. The patients were examined after each cycle and the response was recorded by clinical measurement of the two largest diameters. NAT patients were selected for surgery if satisfactory tumor downstaging was achieved (partial or complete clinical response with no residual tumor larger than $3 \mathrm{~cm}$ in the greatest diameter). The median number of neoadjuvant chemotherapy delivered was three cycles (2-5), and the median time of neoadjuvant endocrine therapy was three months ${ }^{3-5}$.

Our primary aim was to analyze the extent of tissue resection. We estimated volumes of excised tissues using the formula for calculating the volume of an ellipsoid body: $\mathrm{V}=\mathrm{a} \times \mathrm{b} \times \mathrm{c} \times \pi 4 / 3$, where $\mathrm{a}, \mathrm{b}$ and $\mathrm{c}$ are the diameters along the $x, y$ and $z$ axes of a specimen, respectively, according to pathology reports. The diameter of the tumor ( $\mathrm{pT}$ ) corresponded to the largest distance between points on the lesion margin, according to the pathology report. Volume of a tumor mass (Tvol) was calculated using the formula $4 / 3 \pi \times(\mathrm{pT} / 2)^{3}$. The optimal volume required for excision was calculated by adding a resection margin of $1 \mathrm{~cm}$ to the lesion radius and converting this value into a spherical volume using the formula $4 / 3 \pi \times(\mathrm{pT} / 2+1)^{3}$. The actual excess of resected volume was estimated by calculating the resection ratio measured as the volume of the resected specimen divided by the optimal specimen volume ${ }^{16}$. Additionally, we analyzed the correlation between volumes of specimens and volumes of tumors in the EBC and LABC groups (Pearson correlation test).

Our second aim was to ascertain the effect of excess resected tissue on surgical margins. Presence of free surgical margins after primary tumor resections was recorded. All patients showed free surgical margins on intraoperative examination. The final margin status was determined by routine pathological assessments. A negative surgical margin was defined as at least $2 \mathrm{~mm}$ of tumor-free distance from resection margins. We compared the resection 
ratio (RR) between the EBC and LABC groups according to the margin status (Median test). Additionally, we analyzed patient characteristics in the EBC and LABC groups (age and relationships between positive margins and age [Student $t$-test]; histological grade and positive surgical margins [chi-square test]; and volume of resected specimen, pathologic tumor diameter, association between volume and positive surgical margins, and association between diameter and positive margins [Median test]).

\section{Results}

The mean age in the EBC and LABC groups was 56.5 and 53 years $(\mathrm{p}=0.04)$, respectively. Clinical staging showed that in the EBC group, 8 patients had non-palpable lesions, 80 were at stage I, and 103 were at stage II. In the LABC group, 47 patients were at stage II and the remaining 41 were at stage III. The complete pathological response ratio was $13.7 \%$ (11 patients). The main histological type was invasive ductal carcinoma in both groups $(\mathrm{p}=0.4)$.

The median $\mathrm{pT}$ value was $2 \mathrm{~cm}$ (range, $0.35-4.3 \mathrm{~cm}$ ) in the EBC group and $1.5 \mathrm{~cm}$ (range, $0-5 \mathrm{~cm}$ ) in the LABC group $(\mathrm{p}=0.1)$. The median estimated Tvol was $4.1 \mathrm{~cm}^{3}$ (range, $0.002-41.6 \mathrm{~cm}^{3}$ ) in the EBC group and $1.8 \mathrm{~cm}^{3}$ (range, $\left.0-65.4 \mathrm{~cm}^{3}\right)$ in the LABC group $(\mathrm{p}=0.1)$. According to $\mathrm{pT}$ values, the median tissue resection volume required to achieve clear margins by $1 \mathrm{~cm}$ (RVE) was $33.5 \mathrm{~cm}^{3}$ (range, $6.8-131 \mathrm{~cm}^{3}$ ) in the EBC group and $22.4 \mathrm{~cm}^{3}$ (range, $\left.4.1-179.5\right)$ in the LABC group $(\mathrm{p}=0.1)$. The median volume of tissue excised (TVE) was $64.3 \mathrm{~cm}^{3}$ (range, 15.1-375 $\mathrm{cm}^{3}$ ) and $90.7 \mathrm{~cm}^{3}$ (range, 17.1-609 $\mathrm{cm}^{3}$ ) in the EBC and LABC groups ( $\mathrm{p}=0.0007)$, respectively. The median RR was 2.0 (range, $0.43-23.8$ ) and 3.3 (range, $0.4-145.3)$ in the EBC and LABC groups $(\mathrm{p}<0.0001)$, respectively.

The rate of involved surgical margins (ISM) was similar in both groups $(13.1 \%$ and $18.1 \%$ in the EBC and $\mathrm{LABC}$ groups $[\mathrm{p}=0.2]$, respectively). In the EBC group, the median RR was 1.7 (range, 0.5-5.7) among patients with positive margins and 2.0 (range, 0.4-23.8) among patients with negative margins $(\mathrm{p}=0.4)$. In the LABC group, the median RR was 2.0 (range, 0.4-13.5) among patients with positive margins and 4.2 (range, 0.6-145) among those with negative margins ( $\mathrm{p}=0.03)$.

We analyzed the correlation of the volume of resected breast tissue with the $\mathrm{pT}$ and estimated tumor volume (vT) in both groups. In the EBC group, we observed a weak correlation of the volume of resected tissue with $\mathrm{pT}$ and $\mathrm{vT}(\mathrm{r}=0.23, \mathrm{p}=0.001$ for correlation with $\mathrm{pT}$ and $\mathrm{r}=0.19, \mathrm{p}=0.008$ for correlation with $\mathrm{vT})$. In the LABC group, the correlation with $\mathrm{pT}$ was $0.07(\mathrm{p}=0.4)$ and that with vT was $0.13(\mathrm{p}=0.2)$. Table summarizes the patient characteristics and features of resected breast tumor tissues in both groups.

\section{Discussion}

In this study, we assessed some aspects of the volume of resected breast tumor tissues in patients receiving neoadjuvant therapy who underwent BCS. To achieve similar clear margin ratios, surgeons excised a larger volume of tissue from patients treated with neoadjuvant therapy than from patients treated with primary surgery. Extended resection after neoadjuvant therapy was not justified by the residual tumor size or estimated volume. Our data demonstrated that the resection ratio, based on the excised tissue volume to tumor volume ratio, was also higher in patients receiving neoadjuvant therapy than in those undergoing primary surgery. Thus, a large volume of normal breast tissue was excised under such conditions.

Tissue resection during breast-conserving surgeries may be guided by palpation. After neoadjuvant therapy, tumors do not shrink concentrically and residual microscopic lesions may remain, surrounding residual tumor

Table. Clinical and pathological features of 279 patients undergoing breast-conserving surgery

\begin{tabular}{|c|c|c|c|c|c|c|}
\hline & \multicolumn{2}{|c|}{ EBC } & \multicolumn{2}{|c|}{ LABC } & \multicolumn{2}{|c|}{$p$-value } \\
\hline Mean age (years) & \multicolumn{2}{|c|}{56.5} & \multicolumn{2}{|c|}{53.0} & \multicolumn{2}{|c|}{0.04} \\
\hline $\begin{array}{l}\text { Clinical stage } \\
\text { non-palpable } \\
\text { stage I } \\
\text { stage II }\end{array}$ & \multicolumn{2}{|c|}{$\begin{array}{c}8(4.2 \%) \\
80(41.9 \%) \\
103(53.9 \%)\end{array}$} & \multicolumn{2}{|c|}{$\begin{array}{c}0 \\
47(53.4 \%) \\
41(46.6 \%)\end{array}$} & & \\
\hline pT (cm) & \multicolumn{2}{|c|}{$2.0(0.35-4.3)$} & \multicolumn{2}{|c|}{$1.5(0-5.0)$} & \multicolumn{2}{|c|}{0.1} \\
\hline Tvol $\left(\mathrm{cm}^{3}\right)$ & \multicolumn{2}{|c|}{$4.1(0.002-41.6)$} & \multicolumn{2}{|c|}{$1.8(0-65.4)$} & \multicolumn{2}{|c|}{0.1} \\
\hline \multirow[t]{2}{*}{ ISM } & \multicolumn{2}{|c|}{$13.1 \%$} & \multicolumn{2}{|c|}{$18.1 \%$} & \multicolumn{2}{|c|}{0.2} \\
\hline & margins (+) & margins (-) & margins (+) & margins (-) & EBC $p$-value & LABC $p$-value \\
\hline RR & $\begin{array}{c}1.7 \\
(0.5-5.7)\end{array}$ & $\begin{array}{c}2.0 \\
(0.4-23.8)\end{array}$ & $\begin{array}{c}2.0 \\
(0.4-13.5)\end{array}$ & $\begin{array}{c}4.2 \\
(0.6-145)\end{array}$ & 0.4 & 0.03 \\
\hline
\end{tabular}

EBC: early breast cancer group; LABC: locally advanced breast cancer group; PT: diameter os the tumor; Tvol: volume of a tumor mass; TVE: volume of tissue excised; ISM: involved surgical margins; RR: resection ratio. 
lumps ${ }^{17,18}$. Thus, surgeons are obliged to excise larger volumes of breast tissues for safety because the residual tumor lumps may not reflect the actual lesion size or extent. We believe that achieving an adequate surgical margin is important for complete removal of lesions and minimal local recurrences. However, when we compared the volumes of breast tissues excised with positive or negative surgical margins, we observed that the percentages of positive margins were similar between the EBC and LABC groups. We did not observe differences in tumor size or volume between the two groups.

Achieving clear surgical margins is crucial to adequate local control in $\mathrm{BCS}^{19}$. Excising large masses of tissue can jeopardize cosmetic outcomes and does not provide better focal control or better overall survival rates ${ }^{2}$. We found an increase in resection ratios among patients receiving neoadjuvant therapy. The higher RR with clear surgical margins in $\mathrm{LABC}$ patients suggests that generous tissue resections are important for avoiding incomplete tumor excisions. Large resections may be important for including contaminated margins in non-concentrically shrunken tumors.

In a previous prospective controlled trial ${ }^{16}$, the authors reported that use of ultrasound-guided surgery facilitated the excision of tumors of small tissue volumes with clear margins compared to palpation-guided surgery. Such techniques result in favorable cosmetic outcomes. The utility of ultrasound-guided surgery for patients receiving neoadjuvant therapy has not been established yet. It is likely insufficient to identify microscopic residual lesions.

Some studies have proposed the use of magnetic resonance imaging (MRI) for improving the accuracy of resections ${ }^{20}$. Some factors may limit its use for this purpose. For example, depending on the patient's position during the scan, the relationship between tumor and reference points (i.e., the nipple) may vary, reducing the accuracy of the procedure ${ }^{21}$. Another impediment is the cost of testing every patient before surgery.

After neoadjuvant therapy, the use of MRI is useful to estimate the tumor size and the pattern of tumor shrinkage. This preoperative tool reduces the need for re-excision after $\mathrm{BCS}^{22,23}$. However, a recent meta-analysis has demonstrated that preoperative MRI potentially increases the mastectomy ratio ${ }^{24}$. The authors suggest the routine use of preoperative MRI should be abandoned. Some reports have demonstrated the safety of performing BCS after neoadjuvant therapy based on preoperative clinical and mammographic assessment ${ }^{6,7}$. Such observation reinforce the use of adjuvant radiotherapy is highly effective in controlling microscopic residual disease achieving a satisfactory local control BCS $\mathrm{BCS}^{7,25,26}$.

Other imaging techniques use fluorescent markers (fluorochromes) that specifically bind to biomolecules involved in mammary carcinogenesis (e.g., vascular endothelial growth factor receptor, epidermal growth factor receptor, or the HER2/neu receptor). Fluorescent imaging linked to a mobile device allows surgeons to outline tumor masses, identify residual lesions and locate suspicious lymph nodes, facilitating complete eradication of residual lesions with minimal esthetic issues ${ }^{27}$. Despite the importance of these complementary tests to assist in tumor resection, the safety of imaging-guided breast-conserving surgeries is not well established. Its use likely achieves conservative surgery with favorable esthetic outcomes. However, the impact on focal recurrences has not been examined.

We found that, on performing conservative breast surgery after neoadjuvant therapy, the correlation between tumor size and volume of tissues excised was lost, indicating a surgical tendency to remove a large volume of normal breast tissue. This is one of the limitations of preoperative clinical evaluative methods for ascertaining the volume of breast tissue to be excised by conservative breast surgery after adjuvant therapy. Establishment of an optimal technique for ascertaining the excision volume for conservative breast surgery is paramount for achieving reduced local recurrence rates and favorable cosmetic outcomes.

\section{References}

1. Fisher B, Anderson S, Bryant J, Margolese RG, Deutsch M, Fisher $E R$, et al. Twenty-year follow-up of a randomized trial comparing total mastectomy, lumpectomy, and lumpectomy plus irradiation for the treatment of invasive breast cancer. $N$ Engl J Med. 2002;347(16):1233-41.

2. Veronesi U, Banfi A, Salvadori B, Luini A, Saccozzi R, Zucali R, et al. Breast conservation is the treatment of choice in small breast cancer: long-term results of a randomized trial. Eur J Cancer. 1990;26(6):668-70.

3. Schwartz GF, Hortobagyi GN. Proceedings of the consensus conference on neoadjuvant chemotherapy in carcinoma of the breast, April 26-28, 2003, Philadelphia, Pennsylvania. Cancer. 2004; 100(12):2512-32.

4. Chen AM, Meric-Bernstam F, Hunt KK, Thames HD, Outlaw ED, Strom EA, et al. Breast conservation after neoadjuvant chemotherapy. Cancer. 2005; 103(4):689-95.

5. Sadetzki S, Oberman B, Zipple D, Kaufman B, Rizel S, Novikov I, et al. Breast conservation after neoadjuvant chemotherapy. Ann Surg Oncol. 2005;12(6):480-7.

6. Loibl S, von Minckwitz G, Raab G, Blohmer JU, Dan Costa S, Gerber $B$, et al. Surgical procedures after neoadjuvant chemotherapy in 
operable breast cancer: results of the GEPARDUO trial. Ann Surg Oncol. 2006;13(1 1):1434-42.

7. Tiezzi DG, Andrade JM, Marana HR, Zola FE, Peria FM. Breast conserving surgery after neoadjuvant therapy for large primary breast cancer. Eur J Surg Oncol. 2008;34(8):863-7.

8. Al-Ghazal SK, Blamey RW, Stewart J, Morgan AA. The cosmetic outcome in early breast cancer treated with breast conservation. Eur J Surg Oncol. 1999;25(6):566-70.

9. Cochrane RA, Valasiadou P, Wilson AR, Al-Ghazal SK, Macmillan RD. Cosmesis and satisfaction after breast-conserving surgery correlates with the percentage of breast volume excised. Br J Surg. 2003;90(12):1505-9

10. Sneeuw KC, Aaronson NK, Yarnold JR, Broderick M, Regan J, Ross $G$, et al. Cosmetic and functional outcomes of breast conserving treatment for early stage breast cancer. 1. Comparison of patients' ratings, observers' ratings, and objective assessments. Radiother Oncol. 1992;25(3):153-9.

11. Taylor ME, Perez CA, Halverson KJ, Kuske RR, Philpott GW, Garcia DM, et al. Factors influencing cosmetic results after conservation therapy for breast cancer. Int J Radiat Oncol Biol Phys. 1995;31 (4):753-64.

12. Menes TS, Tartter PI, Bleiweiss I, Godbold JH, Estabrook A, Smith $\mathrm{SR}$. The consequence of multiple re-excisions to obtain clear lumpectomy margins in breast cancer patients. Ann Surg Oncol. $2005 ; 12(11): 881-5$.

13. McLaughlin SA, Ochoa-Frongia LM, Patil SM, Cody HS 3rd, Sclafani LM. Influence of frozen-section analysis of sentinel lymph node and lumpectomy margin status on reoperation rates in patients undergoing breast-conservation therapy. J Am Coll Surg. 2008;206(1):76-82.

14. Mullenix PS, Cuadrado DG, Steele SR, Martin M, See CS, Beitler $\mathrm{AL}$, et al. Secondary operations are frequently required to complete the surgical phase of therapy in the era of breast conservation and sentinel lymph node biopsy. Am J Surg. 2004; 187(5):643-6.

15. Andrade JM, Carrara HH, Pimentel FF, Marana HR, Macchetti AH, Mouro LR, et al. Taxane-based chemotherapy enhances response to neoadjuvant treatment for stage II and III breast cancer. Med Oncol. 2011;28 Suppl 1:S65-9.

16. Krekel NM, Haloua MH, Lopes Cardozo AM, de Wit RH, Bosch $A M$, de Widt-Levert $L M$, et al. Intraoperative ultrasound guidance for palpable breast cancer excision (COBALT trial): a multicentre, randomised controlled trial. Lancet Oncol. 2013;14(1):48-54.
17. van der Hage JA, van de Velde CJ, Julien JP, Tubiana-Hulin M, Vandervelden C, Duchateau L. Preoperative chemotherapy in primary operable breast cancer: results from the European Organization for Research and Treatment of Cancer trial 10902. J Clin Oncol. 2001;19(22):4224-37.

18. Veronesi U, Bonadonna G, Zurrida S, Galimberti V, Greco M, Brambilla $C$, et al. Conservation surgery after primary chemotherapy in large carcinomas of the breast. Ann Surg. 1995;222(5):612-8.

19. Morrow M, Strom EA, Bassett LW, Dershaw DD, Fowble B, Giuliano $A$, et al. Standard for breast conservation therapy in the management of invasive breast carcinoma. CA Cancer J Clin. 2002;52(5):277-300.

20. Yamashiro N, Tozaki M, Ogawa T, Kawano N, Suzuki T, Ozaki $S$, et al. Preoperative MRI marking technique for the planning of breast-conserving surgery. Breast Cancer. 2009; 16(3):223-8.

21. Tozaki M, Fukuda K. Supine MR mammography using VIBE with parallel acquisition technique for the planning of breast-conserving surgery: clinical feasibility. Breast. 2006;15(1):137-40.

22. Mann RM, Loo CE, Wobbes T, Bult P, Barentsz JO, Gilhuijs KG, et al. The impact of preoperative breast MRI on the re-excision rate in invasive lobular carcinoma of the breast. Breast Cancer Res Treat. 2010;119(2):415-22.

23. McGhan L, Wasif N, Gray RJ, Giurescu ME, Pizzitola VJ, Lorans $R$, et al. Use of preoperative magnetic resonance imaging for invasive lobular cancer: good, better, but maybe not the best? Ann Surg Oncol. 2010;17 Suppl 3:255-62. doi:10.1245/s10434010-1266-y

24. Houssami N, Turner R, Morrow M. Preoperative magnetic resonance imaging in breast cancer: meta-analysis of surgical outcomes. Ann Surg. 2013;257(2):249-55.

25. Fisher B, Brown A, Mamounas E, Wieand S, Robidoux A, Margolese $R G$, et al. Effect of preoperative chemotherapy on local-regional disease in women with operable breast cancer: findings from National Surgical Adjuvant Breast and Bowel Project B-18. J Clin Oncol. 1997;15(7):2483-93

26. Pleijhuis RG, Graafland M, de Vries J, Bart J, de Jong JS, van Dam GM. Obtaining adequate surgical margins in breast-conserving therapy for patients with early-stage breast cancer: current modalities and future directions. Ann Surg Oncol. 2009;16(10):2717-30.

27. Frangioni JV. New technologies for human cancer imaging. J Clin Oncol. 2008;26(24):4012-21. 